\title{
CONTENT ANALYSIS APPLIED TO SOCIAL AND ENVIRONMENTAL REPORTING
}

\author{
[Obsahová analýza aplikovaná na sociální a environmentální vykazování]
}

\author{
Michaela Horúcková ${ }^{1}$, Thierry Baudassé2 \\ ${ }^{1}$ Silesian University, School of Business Administration, Univerzitni nám. 1934/3, 73340 Karvina \\ Email: horuckova@opf.slu.cz
}

${ }^{2}$ Université d'Orléans, Faculté de Droit, Economie et Gestion, Laboratoire d'Économie d'Orléans, UMR 7322

CNRS, Rue de Blois-BP26739, Orléans Cedex 2, France

Email: thierry.baudasse@univ-orleans.fr

\begin{abstract}
Content analysis is an accredited research technique that despite its increasing use in numerous disciplines and substantial expansion in academia lacks a unified methodology and rigorous methodological standards. This paper presents the technique of content analysis and the way it can be applied to social and environmental reporting, with a special focus on environmental corporate reporting. Major methodological problems that have been raised by the use of content analysis, and unique coding rules and decisions developed by authors are presented. Through the application of content analysis on CEZ Group's corporate report, possible outcomes that can be obtained while using this technique are shown.
\end{abstract}

Keywords: content analysis, corporate reporting, corporate social responsibility, environmental reporting.

JEL classification: F64, Q40, Q50, Q56

Doručeno redakci: 26.9.2017; Recenzováno: 17.10.2017; 25.10.2017; Schváleno k publikování: 13.12.2017

\section{Introduction}

Content analysis is a method known for hundreds of years and can be seen already in literature of $16^{\text {th }}$ century (Krippendorff 2004). The first original conceptualization appeared in early fifties of twentieth century when Berelson (1952) provided the first integrated picture of content analysis. Since this moment, the use of content analysis has spread in numerous disciplines, mainly in social and human sciences as journalism, sociology, psychology, anthropology, history, economics, and business. The use of content analysis applies in other fields such as medicine or politics (Krippendorff 2004; Neuendorf 2017).

Content analysis as an accredited research technique has also achieved a substantial expansion in academia that can be demonstrated by the fact that since 1980s, the number of publications containing content analysis has sharply increased (Neuendorf 2017). Despite this fact, the research lacks a unified methodology and rigorous methodological standards. However, the lack of unified methodology gives a space for own realization and development of own methodology.

The aim of this paper is to present the unique methodology of content analysis and the way it can be applied in order to make quantitative analysis of qualitative sources. More precisely, this technique is applied to the field of environmental economics. After presenting the nature and challenges of social and environmental reporting (section 2), methodological issues of content analysis (section 3) and its design applied to environmental research (section 4) is presented. Subsequently, the designed content analysis is applied to CEZ Group's corporate report (section 5). Section 6 concludes. 


\section{Social and environmental reporting}

Social and environmental disclosures are nowadays an integral part of reporting of many companies. Companies publish such type of information in order to report on their activities that go beyond company's main objective, which is the profit maximization, and that are related to the responsible behaviour of the business. Such company strives for responsible behaviour towards their employees, society, and the environment. The concept of responsible business is based on so called stakeholders and legitimacy theories that gave rise to the notion of corporate social responsibility (CSR) underlying corporate self-regulation integrated into a business model.

Friedman's (1962) shareholder theory (also known as stockholder theory) assumes that the profit generation is the sole responsibility of a business as the core interest of business owners is the profit maximization. Freeman and Reed (1983) came up with a new theory that emphasises, unlike shareholder theory, the responsibility of the company towards the wider group of stakeholders rather than shareholders. They defined stakeholders as "groups who can affect or are affected by the achievement of an organization's purpose" (Freeman and Reed 1983 , p. 91). These groups are persons, groups, neighbourhoods, organizations, institutions, societies, but also the natural environment and media (Mitchell et al. 1997; Tilling 2004). Stakeholder theory combines morals and values, often neglected by shareholders, with organizational management and business ethics.

Environmental research frequently refers also to legitimacy theory that is one of the most cited theories within social and environmental accounting, even if this theory is still underdeveloped (see for example Cuganesan et al. 2010; Hrasky 2012; O’Donovan 2002; or van Staden and Hooks 2007). Suchman (1995) described legitimacy as "a generalized perception or assumption that the actions of an entity are desirable, proper, or appropriate within some socially constructed system of norms, values, beliefs, and definitions" (1995, p. 574). O'Donovan (2000, p. 79) defines legitimacy as "the process whereby a corporation justifies to its conferring publics its right to continue to operate". The basic elements of the theory perceptions and assumptions - need to be accompanied by public disclosures such as those in annual reports, sustainability reports, corporate social reports and other company's publications. Legitimacy theory is closely associated with the concept of corporate social responsibility. This concept represents policies and practices of companies, organizations, or individuals, which integrate environmental and social matters into their business strategies and daily practices (Sapkauskiene and Leitoniene 2014). Wood (1991, p. 695) accentuates that "business and society are interwoven rather than distinct entities and therefore, society has certain expectations for appropriate business behaviour and outcomes". Legitimacy theory can be also characterized as the ethical behaviour of the company represented by its managers, towards the society represented by its stakeholders (O'Donovan 2000). Bravo et al. (2012) point out the fact that the communication of CSR activities can help companies to construct its identity and to reach positive outcomes.

CSR activities are basically communicated through the aforementioned public disclosures contained in company's publications (reports). Traditionally, social and environmental disclosures formed a part of annual reports. More recently, they used to be present in standalone reports. The non-financial reporting has become to be the centre of interest of national and international frameworks proposing guidelines for corporate reporting on non-financial issues (e.g. United Nations (UN) Global Compact, the Global Reporting Initiative). The CSR literature tends to recognize that such self-reporting may be undertaken voluntarily, as a result of legislation, or as a part of a code of practice (Gray et al. 1995b). While originally, the concept 
of CSR reporting was based on voluntarily action of the companies, nowadays we encounter, for example, binding regulation of the EU in form of EU Directive on disclosure of nonfinancial and diversity information $(2014 / 95 / \mathrm{EU})^{1}$. This directive binds certain large publicinterests undertakings and groups having more than 500 employees to publish their impact of businesses on society. Nevertheless, corporate social responsibility (CSR) is "concerned with the ways in which an organisation exceeds its minimum obligations to stakeholders specified through regulation" (Johnson, G. et al. 2008, p. 146).

Abbott and Monsen (1979) outlined three methods of measuring corporate social activities social accounting, reputational scale, and content analysis. The most prevailing method in CSR research that consists of social and environmental disclosures is content analysis (Milne and Adler 1998; Parker 2005; Sweeney and Coughlan 2011; Sapkauskiene and Leitoniene 2014). This method enables researchers to produce valid and trustworthy inferences based on analysis of written, spoken, imagery, and audio-visual media.

\section{Methodological issues of content analysis}

The conceptualization of content analysis began with Berelson's (1952) definition of content analysis as "a research technique for the objective, systematic and quantitative description of the manifest content of communication" (p. 18). Other significant contributors were, for instance, Abbott and Monsen (1979) who provided richer definition of content analysis: "Content analysis is a technique for gathering data that consists of codifying qualitative information in anecdotal and literary form into categories for deriving quantitative scales of varying levels of complexity" (p. 504), or Krippendorff (1980) who described content analysis as "a research technique for making replicable and valid inference from data according to their context" (p. 21). Krippendorff was also the first author who provided a comprehensive and very detailed methodology of content analysis design for analysts who rely basically on available texts to answer their research question(s) (Krippendorff 1980, 2004). His methodology remains the one of very frequently followed methodologies.

In this paper, content analysis is selected as method of measuring corporate social activities. This method enables, on the basis of qualitative documentary analysis, to derive patterns in the presentation and reporting of information (Guthrie and Abeysekera 2006), and make conclusions on:

- How does the company present its awareness of investigated issues;

- How much is the firm involved in tackling with these issues;

- How much is the firm self-regulating;

- How responsible and sustainable is its business behaviour, and many others.

The main limitation of content analysis inheres in its subjectivity (Guthrie and Abeysekera 2006). Objectivity cannot be measured, neither tested (Krippendorff 2004) but its desirable (Neuendorf 2017). Nevertheless, the subjectivity of content analysis can be lessened by using more than one coder (rater) and testing statistically the level of inter-rater agreement by using Cohen's Kappa index (often called by Kappa, or Kappa statistics/test) ${ }^{2}$. Cohen's (1960) Kappa measures the (dis)agreement between two coders who are emitting a judgement about a situation.

\footnotetext{
${ }^{1}$ The directive entered into force in December 2014

${ }^{2}$ Krippendorff (2004, pp. 246 sqq.) criticizes Cohen's kappa index and argues that Scott (1955) reliability index (also noted $\pi$ index) is more relevant.
} 
There is a certain probability that these 2 judges emitted the same judgement "by chance". This probability can be noted $\mathrm{p}_{\mathrm{c}}$, which denotes the probability than judges could agree by chance on any of the judgements. So, when considering the real proportion of agreement $\mathrm{p}_{0}$, we have to compare it to the value of $\mathrm{p}_{\mathrm{c}}$. The Kappa coefficient $\kappa$ is therefore defined as the following ratio:

$$
\kappa=\frac{p_{o}-p_{c}}{1-p_{c}}
$$

$\kappa$ is in the interval $[-1,1]$ where:

$\kappa=1 \quad$ Perfect agreement

$\kappa=(0,1) \quad$ Partial agreement

$\kappa=(-1,0]$ Disagreement

$\kappa=-1 \quad$ Perfect disagreement.

Current literature also revealed an important finding related to the influence of the country of domicile, company's size and industry on disclosures (e.g. Beck et al. 2010). For example, Buhr and Freedman (2001, p. 303) concluded that "similar sized companies in the same industry should have similar environmental impact and therefore, ideally, similar disclosure". There are numerous CSR studies focused on specific industry, for example, Cuganesan et al. (2010) deal with Australian food and beverage industry; Pesci and Costa (2014) with Italian banking sector, or Bravo et al. (2012) that focused on banking sector in Spain. Notwithstanding, there is a literature that assesses CSR disclosure across industries (for example, Hooks and van Staden 2011; Beck et al. 2010; van Staden and Hooks 2007). Cuganesan et al. (2010) emphasize the necessity to respect industry specificities when formulating and assessing CSR disclosures, as the nature of a company's industry was obviously affecting them.

Krippendorff (2004) distinguishes two basic steps in content analysis - its 'development' within which the content analysis design emerges, and its 'execution' that follows relatively fixed content analysis design.

The first step in content analysis lies in a choice of media used (Krippendorff 1980; Unerman 1999, Krippendorff 2004). The number of media used in content analysis studies has evolved over time. Frequently used media, and in majority of cases the sole media, used in environmental and social reporting research is the annual report. Annual reports represent the main form of corporate communication and have high degree of credibility (Guthrie and Abeysekera 2006; Unerman 1999; Sapkauskiene and Leitoniene 2014). In recent years, other alternative corporate reporting medias such as stand-alone reports (sustainable reports, triple bottom line, CSR reports, stand-alone environmental reports), or Internet reporting, are used (van Staden and Hooks 2007; Cuganesan et al. 2010). Bravo et al. (2012) underlined the necessity to consider additional materials than CSR reports. Guthrie and Abeysekera (2006) stressed that combinations of several media should provide more robust empirical evidence for understanding of companies' practices. These media are designed to intentionally communicate socially responsible behaviour of companies with their stakeholders and some studies emphasize their non-exclusiveness from analysis, or even demonstrate prevalence in company's communication (for example Unerman 1999). Companies can communicate with their stakeholders through other channels than aforesaid, as press releases or advertisements, but the range of media used can be associated with company size and for this reason, a limit of 
media in study has to be set (Gray et al. 1995a). Several authors (for example Roberts 1991; Unerman 1999) pointed out that the exclusive focus on annual reports may arise in incomplete picture of companies' practices. Van Staden and Hooks (2007) laid stress on necessity to avoid doubling of information that could appear in both annual and environmental reports.

If the decision on media used in the study is made, the question of what measuring method of content analysis is used takes place. There are various methods of measuring disclosures. The decision on what method is used depends on author's approach in the study. In the social and environmental accounting literature, two groups of content analysis studies are distinguished. The first group stems from the extent of reporting and used to be labelled as extent-based/narrative/mechanistic (hereinafter mechanistic) and conversely, the second group is based on the quality of reporting and is denoted quality-based/interpretative (hereinafter interpretative).

The mechanistic approach is based on the key assumption that volumetric or frequency capture of character, word, sentences, rows, page or volume proportion, or frequency of disclosures, signifies the importance of disclosure category (Unerman 1999; Beck et al. 2010; Hooks and van Staden 2011). The analysis using the narrative approach used to be labelled as quantitative content analysis due to its focus on accounting of captured data and no emphasis on the quality of provided information (Guthrie and Abeysekera 2006). Nonetheless, accuracy of this volumetric or frequency capture is the subject of many studies that pointed out the fact that different measurement technique may result in different picture of relative importance of the given category (e.g. Zéghal and Ahmed 1990; Hackston and Milne 1996; Unerman 1999; Cuganesan et al. 2010). Insight into the determination of measurement method of underlying studies (e.g. Unerman 1990; Milne and Adler 1998; Beattie and Thomson 2007; Cuganesan et al. 2010) shows that in terms of accuracy, sentence counts prevails over the character and word counts due to its ability to convey meaning of sentence what cannot be achieved while counting words. The use of sentence and page proportion counts prevails in many studies (Milne and Adler 1998). According to Cuganesan et al. (2010), the sentence count is the most suitable unit to draw conclusions because of its characteristic to capture also visuals. In order to remain with sentence counting but include also visuals (except pictures/photographs), van Staden and Hooks (2007) employ tables, graphs and figures by a standard sentence of 15 words. Unerman (1990) considers that the method of sentence counts and measurement in terms of proportion of pages are similarly unsatisfactory, as the variance in grammar use of different writers can result in providing the same message while using different number of sentences. Nevertheless, the use of proportion of pages may eliminate the risk of measurement error and enable to capture visual disclosures (graphs and photographs). However, the coding of imageries is also the subject of discussions. While some authors claimed that imageries may be even more powerful tool in company's communication towards stakeholders than narrative disclosures (see, for example, Pesci and Costa 2014), some authors pointed out the fact that it can be used as 'green-washing' tool that can manipulate meaning of the message (for example Hrasky 2012). Nevertheless, Milne and Adler (1998) undermined the reliability of page proportion count and state that "laying a plastic grid sheet over a body of text and trying to code the contents of each grid square would result in meaningless measures" (p. 243). Based on this statement, they advocated the use of sentences in order to provide complete, reliable and meaningful data for subsequent analysis. Krippendorff $(2004$, p. 86) pointed out the fact that "the use of inappropriate units leads analysts to experience conceptual trouble".

Conversely, the interpretative approach focus attention on quality and richness of narratives (Beck et al. 2010). The use of interpretative approach aims to "gain greater understanding of 
what is communicated and how [...] and tends towards interpretation of text rather than attempting to record the mechanics of its conveyance" (Beck et al. 2010, p. 208). For this reason, this approach used to be labelled as 'qualitative'. Quality-based content analysis usually consists in quality index scores (Pesci and Costa 2014)

Nevertheless, studies that are based on the combination of these two approaches are not exceptional (for example Beck et al. 2010). According to Krippendorff (2004), the content analysis should consist of both - quantification and qualification - as those two are indispensable. Van Staden and Hooks (2007) verified that there is a positive relation between the quality and extent of environmental disclosure and environmental responsiveness.

In order to analyse the data from investigated media, the formulation of a set of categories and coding rules is necessary. To have the highest significance of resulted data, it is necessary to make the categorization and rules as close as possible to the issue under consideration. Abbott and Monsen (1979) accentuated that insufficient reflection of all the issues actually contained in the report while formulating categories and/or inaccurate coding data could affect the validity and reliability of the resulting scale. The investigated issues (e.g. environmental pollution) should "reflect the criticisms that are currently being encountered by the modern cooperation and also are the targets of governmental regulation" (Abbott and Monsen 1979, p. 506). In order to achieve a certain quality of content analysis, some processes in content analysis may be iterative (Krippendorff 2004).

\section{Design of the content analysis applied to environmental research}

The methodological design of content analysis in this paper largely follows the Krippendorffs' methodology (2004).

Content analysis processed in this study is based on both mechanistic and interpretative approach and is conducted 'manually' assisted by qualitative data analysis software for researchers NVivo. The processing of content analysis follows unique classification/decision rules and classification schemes developed by the authors on the base of several research papers (van Staden and Hooks 2007; Beck et al. 2010; Cuganesan et al. 2010; Hooks and van Staden 2011), methodologies provided (Krippendorff 2004; Neuendorf 2017), and Global Reporting Initiative standards (GRI 2016). Authors of this paper also took in consideration current energy and environmental challenges, governmental regulations and other legal acts, and all other important issues related to the investigated topic.

The content analysis and classification rules and schemes developed in this paper are applied to corporate reporting of energy conglomerate CEZ Group (hereinafter also referred to as "CEZ" or "Group"). Results of content analysis are described in Section 4.

Content analysis requires indisputable and unambiguous classification/decisions rules that have to be clearly defined.

The classification/decisions (coding) rules developed by the authors are the following:

1. Only information related to the company's practices and/or policies are considered as disclosures.

2. The basic coding unit is a sentence. But if the following sentence(s) begin(s) by conjunctive adverb(s) and/or follow(s)/complement(s) the previous statement without possibility to be isolated, they are considered as one sentence. The author decided to implement this rule based on preliminary study. This study confirmed that each author has a different grammar use. While one author can use one sentence to fully convey the 
given information, there are cases in which one sentence cannot express given idea/information while remaining clear. In such cases, authors used two or more followup sentences to provide single information. For example, CEZ states in its annual report (2016) the following: "Strengthening of the position of CEZ Group in the field of renewable energy sources in Central and Western Europe is one of the main objectives of the updated strategy of CEZ Group. In this context, CEZ announced in April 2016 its strategic intention to invest heavily in renewable energy sources, in the development of decentralized technologies and innovative solutions in Western markets (especially in renewable sources in Germany)." (CEZ 2017, p. 124). If the second sentence stands alone, it is very difficult to guess in 'what context' ČEZ announced its strategic intention, and thus it is necessary to keep together both sentences in order to preserve the meaning and integrity of the given information.

3. Tables, graphs and imageries containing figures are coded as disclosure only if they provide unique information not mentioned in the previous/following text.

4. Pictures that do not provide any numbers and/or information on company's policy are not included in the analysis as their interpretation is influenced by subjectivity that can lead to their misinterpretation and/or that can manipulate the meaning of the message.

5. Tables/paragraphs that contain information on policy or area of action using bullets and belonging to one group are considered as a single sentence. Otherwise, each bullet is coded into individual disclosure area according to its message.

6. Content of the report, headings and other document elements serving for navigation in the documents (e.g. headers and footers) are excluded from the analysis.

7. If the disclosure consists of several facts, the significantly prevailing information decides on placement of the disclosure in a certain category. If the disclosure classification is ambiguous or questionable, the disclosure is categorized as 'general' disclosure.

8. The information that cannot be assigned to any of the given categories is coded into category 'general'.

The core classification/coding scheme is twofold.

Each disclosure is classified according to the disclosure type as narrative, narrativecomparative, quantitative, or quantitative-comparative (see Table 1.). This classification allows making conclusions on the depth of information provided. It is expected that comparisons provide deeper information that acquires the analyst with the previous situation and state of play, and that numerical disclosures usually provide more measureable information.

Table 1: Disclosure Types and Example of Information Disclosed by CEZ Group

\begin{tabular}{lll}
\hline Disclosure type & Definition & Example of CEZ Group \\
\hline Narrative & $\begin{array}{l}\text { Environmental disclosures providing details or clearly } \\
\text { evident impact(s) of the company or its policies related } \\
\text { to the category }\end{array}$ & $\begin{array}{l}\text { "CEZ Group's business activities are governed by strict ethical } \\
\text { standards that include responsible behaviour toward employees, } \\
\text { society, and the environment." (CEZ, 2017, p. 2) }\end{array}$ \\
Narrative-comparative & $\begin{array}{l}\text { Any narrative environmental disclosure that } \\
\text { demonstrates any comparisons or benchmarking against } \\
\text { best practice }\end{array}$ & - \\
Quantitative & $\begin{array}{l}\text { Environmental disclosures capturing any quantitative } \\
\text { explanations related to the category }\end{array}$ & $\begin{array}{l}\text { "Dust particles are captured by electrostatic precipitators or bag } \\
\text { filters; the efficiency of separation of these pollutants is around }\end{array}$ \\
Quantitative-comparative & $\begin{array}{l}\text { Any numerical environmental disclosure that } \\
\text { demonstrates any comparisons or benchmarking against } \\
\text { best practice }\end{array}$ & $\begin{array}{l}\text { "In 2016 and 2015, the payments to the nuclear account amounted to } \\
\text { CZK 1,205 million and CZK 1,342 million, respectively." (CEZ, }\end{array}$ \\
\hline
\end{tabular}

Source: Own processing

Given the fact that in most of the cases, company reports are very extensive, certain information could be in the amount of text overlooked, seemed as more/less important, or can lead to wrong 
interpretation. For this reason, each disclosure is categorized into pre-set categories and subcategories (see Table 2.). This categorization permits the researcher to make trustworthy inferences from company reports and recognize, which area of information is key to the company, and what weight is given to it.

Table 2: Disclosure Areas and Example of Information Disclosed by CEZ Group

\begin{tabular}{|c|c|c|c|}
\hline Category & Subcategory & Definition & Example of CEZ Group \\
\hline General & -- & $\begin{array}{l}\text { General environmental disclosures related to the } \\
\text { company's mission, vision, objectives, policies, } \\
\text { concerns for the environment, environmental or } \\
\text { energy management policy, system and processes } \\
\text { that do not fit in any of below-mentioned category }\end{array}$ & $\begin{array}{l}\text { "CEZ Group's mission is to provide safe, reliable, } \\
\text { and positive energy to its customers and society as } \\
\text { a whole; its goal is to bring innovations for } \\
\text { resolving energy needs and to help improve the } \\
\text { quality of life." (CEZ 2017, p. 2) }\end{array}$ \\
\hline \multirow[t]{4}{*}{$\begin{array}{l}\text { Energy related } \\
\text { disclosures }\end{array}$} & $\begin{array}{l}\text { General Energy } \\
\text { Disclosure }\end{array}$ & $\begin{array}{l}\text { Any general energy disclosure that shows evident } \\
\text { impact of company's energy policy and/or action } \\
\text { that cannot be placed in any specific energy related } \\
\text { disclosures category }\end{array}$ & $\begin{array}{l}\text { "An energy management system (EnMS) } \\
\text { according to ISO 50001 has been gradually } \\
\text { introduced in CEZ Group since 2015. [...]." (CEZ } \\
\text { 2017, p. 82) }\end{array}$ \\
\hline & Energy Efficiency & $\begin{array}{l}\text { Environmental disclosures related to the energy } \\
\text { efficiency (energy transition; energy saving } \\
\text { measures, saving/conservation, opportunities } \\
\text { and investment; and promoting of energy } \\
\text { efficiency) }\end{array}$ & $\begin{array}{l}\text { "ČEZ ESCO, a member of CEZ Group, } \\
\text { consolidates the Group's expert and sales capacity } \\
\text { in energy savings, decentralized sources, lighting, } \\
\text { and other energy products. [...]." (CEZ 2017, p. } \\
\text { 105) }\end{array}$ \\
\hline & Energy Security & $\begin{array}{l}\text { Any environmental disclosure related to the } \\
\text { uninterrupted availability of energy sources at an } \\
\text { affordable price }\end{array}$ & $\begin{array}{l}\text { "In order to mitigate the risk of an interruption or } \\
\text { other threats to timely supplies of nuclear fuel, } \\
\text { ČEZ decided to increase the share of fuel } \\
\text { fabricated [...]." (CEZ 2017, p. 101) }\end{array}$ \\
\hline & $\begin{array}{l}\text { Energy } \\
\text { Sustainability }\end{array}$ & $\begin{array}{l}\text { Environmental disclosures related to the use of } \\
\text { renewable energy sources, development, } \\
\text { exploration and investment in alternative energy } \\
\text { sources as well as investment in R\&D in this area }\end{array}$ & $\begin{array}{l}\text { "In } 2016 \text {, generation was performed only in the } \\
\text { photovoltaic power plant in Oreshets." (CEZ } \\
2017 \text {, p. 113) }\end{array}$ \\
\hline \multirow[t]{10}{*}{$\begin{array}{l}\text { Environmental } \\
\text { protection } \\
\text { related } \\
\text { disclosures }\end{array}$} & $\begin{array}{l}\text { General } \\
\text { Environmental } \\
\text { Disclosures }\end{array}$ & $\begin{array}{l}\text { Any general energy disclosure that shows evident } \\
\text { impact of company's environmental policy and/or } \\
\text { action that cannot be placed in any specific energy } \\
\text { related disclosures category }\end{array}$ & $\begin{array}{l}\text { "CEZ Group places permanent emphasis on } \\
\text { environmental care and protection in the vicinity } \\
\text { of its sites." (CEZ 2017, p. 143) }\end{array}$ \\
\hline & $\begin{array}{l}\text { Air Pollution } \\
\text { related Disclosures } \\
\text { (excl. GHG } \\
\text { emissions) }\end{array}$ & $\begin{array}{l}\text { Environmental issues related to the six common air } \\
\text { pollutants caused by human activity the ozone } \\
\text { molecule }\left(\mathrm{O}_{3}\right) \text {, particle matter (PM), Carbon } \\
\text { Monoxide, } \mathrm{CO} \text {; lead }(\mathrm{Pb}) \text {; Sulphur Dioxide, } \mathrm{SO}_{2} \text {; } \\
\text { Nitrogen Dioxide, } \mathrm{NO}_{2}\end{array}$ & $\begin{array}{l}\text { "To decrease the amounts of pollutants released to } \\
\text { the air, combustion facilities operated by CEZ } \\
\text { Group are fitted with emission reduction } \\
\text { equipment." (CEZ 2017, p. 141) }\end{array}$ \\
\hline & $\begin{array}{l}\text { Biodiversity } \\
\text { Protection } \\
\text { and Preservation }\end{array}$ & $\begin{array}{l}\text { Environmental disclosures related to the protection } \\
\text { of natural habitat/species }\end{array}$ & $\begin{array}{l}\text { "Considerate decommissioning of old pits helps } \\
\text { preserve and develop protected species' habitats in } \\
\text { the area." (CEZ 2017, p. 23) }\end{array}$ \\
\hline & $\begin{array}{l}\text { Energy safety } \\
\text { (excl. exclusive } \\
\text { focus on Nuclear) }\end{array}$ & $\begin{array}{l}\text { Environment disclosures related to the monitoring, } \\
\text { assessing and prevention of risks related to the } \\
\text { energy generation, distribution etc. excluding } \\
\text { nuclear safety }\end{array}$ & $\begin{array}{l}\text { "CEZ Group's internal regulations give priority to } \\
\text { safety and security in all processes and activities." } \\
\text { (CEZ 2017, p. 82) }\end{array}$ \\
\hline & $\begin{array}{l}\text { GHG emissions } \\
\text { related Disclosures }\end{array}$ & $\begin{array}{l}\text { Environmental issues } \\
\text { production/reduction of Carbon Dioxide, } \mathrm{CO}_{2} \text {; } \\
\text { Methane, CH4; Nitrous Oxide, N2O; } \\
\text { and/or Fluorinated gases incl. Hydrofluorocarbons, } \\
\text { HFCs; Perfluorocarbons, PFCs; and Sulphur } \\
\text { Hexafluoride SF6 and related topics. }\end{array}$ & $\begin{array}{l}\text { "In 2016, CEZ Group [...] had invested over CZK } \\
220 \text { million in clean, environmentally friendly } \\
\text { technologies." (CEZ 2017, p. 141) }\end{array}$ \\
\hline & $\begin{array}{l}\text { Land Pollution } \\
\text { related Disclosures }\end{array}$ & $\begin{array}{l}\text { Environmental disclosures related to the } \\
\text { deterioration (destruction of the earth's land } \\
\text { surfaces as a result of company's activities) }\end{array}$ & $\begin{array}{l}\text { "The provision for decommissioning and } \\
\text { reclamation of mines and mining damages was } \\
\text { recorded by Severočeské doly a.s., a mining } \\
\text { subsidiary of ČEZ." (CEZ 2017, p. 257) }\end{array}$ \\
\hline & $\begin{array}{l}\text { Natural Resources } \\
\text { Preservation }\end{array}$ & $\begin{array}{l}\text { Environmental disclosures related to the natural } \\
\text { resources, water and energy consumption }\end{array}$ & -- \\
\hline & $\begin{array}{l}\text { Noise Pollution } \\
\text { related Disclosures }\end{array}$ & $\begin{array}{l}\text { Environmental disclosures related to the industrial } \\
\text { production noise emissions }\end{array}$ & $\begin{array}{l}\text { "CEZ Group facilities meet hygienic noise limits } \\
\text { in accordance with the legislation and conditions } \\
\text { of the applicable authorizations." (CEZ 2017, p. } \\
144 \text { ) }\end{array}$ \\
\hline & Nuclear safety & $\begin{array}{l}\text { Environment disclosures related to the monitoring, } \\
\text { assessing and prevention of nuclear risk }\end{array}$ & $\begin{array}{l}\text { "ČEZ pays significant attention to long-term } \\
\text { research in the field of safety of nuclear power } \\
\text { plants and their resilience following the accident at } \\
\text { the Fukushima Nuclear Power Plant." (CEZ 2017, } \\
\text { p. 130) }\end{array}$ \\
\hline & $\begin{array}{l}\text { Water Pollution } \\
\text { related Disclosures }\end{array}$ & $\begin{array}{l}\text { Environmental disclosures related to the } \\
\text { (de)contamination of water }\end{array}$ & $\begin{array}{l}\text { "Regular monitoring of surface water and } \\
\text { groundwater is carried out in power plants." (CEZ } \\
2017 \text {, p. 142) }\end{array}$ \\
\hline
\end{tabular}

Source: Own processing 
The cases of energy and environmental (non-)compliance are coded separately from the two core coding sheets: Disclosure types (Table 1.) and Disclosure areas (Table 2.). This is given by the fact that each disclosure of this type can be addressed to three questions: (1) What is the type of disclosure; (2) What is the area of the policy (this information is coded at the level of disclosure areas according to the scheme provided in Table 2.); and when applicable: (3) What is the level of compliance with legally binding policies, or what is the additional effort of the company to pursue its policies and/or CSR practices towards the environment.

Table 3: Cases of Energy or Environmental (Non-)Compliance and Example of Information Disclosed by CEZ Group

\begin{tabular}{|c|c|c|}
\hline Category & Definition & Example of CEZ Group \\
\hline Energy compliance & $\begin{array}{l}\text { Environmental disclosures referring to the energy } \\
\text { compliance with international declarations, conventions and } \\
\text { treaties; all level regulations, recommendations and } \\
\text { directives }\end{array}$ & $\begin{array}{l}\text { "ČEZ's nuclear power plants were operated in compliance } \\
\text { with applicable nuclear energy legislation in 2016, fulfilling } \\
\text { the conditions of all valid licenses." (CEZ 2017, p. 83) }\end{array}$ \\
\hline Energy non-compliance & $\begin{array}{l}\text { Environmental energy related disclosures referring } \\
\text { to the international disputes and cases of energy non- } \\
\text { compliance }\end{array}$ & -- \\
\hline Voluntary energy compliance & $\begin{array}{l}\text { Environmental disclosures related to the voluntary energy } \\
\text { agreements; standards and certification }\end{array}$ & $\begin{array}{l}\text { "An energy management system (EnMS) according to ISO } \\
50001 \text { has been gradually introduced in CEZ Group since } \\
\text { 2015. [...]." (CEZ 2017, p. 82) }\end{array}$ \\
\hline Environmental Compliance & $\begin{array}{l}\text { Environmental disclosures referring to the environmental } \\
\text { compliance with international declarations, conventions } \\
\text { and treaties; all level regulations, recommendations } \\
\text { and directives }\end{array}$ & $\begin{array}{l}\text { "CEZ Group facilities meet hygienic noise limits } \\
\text { in accordance with the legislation and conditions } \\
\text { of the applicable authorizations." (CEZ 2017, p. 144) }\end{array}$ \\
\hline Environmental Non-Compliance & $\begin{array}{l}\text { Environmental disclosures related to the international } \\
\text { disputes and cases of environmental non-compliance }\end{array}$ & $\begin{array}{l}\text { "The Varna Coal-Fired Power Plant did not generate any } \\
\text { electricity or heat in } 2016 \text { because its operation was suspended } \\
\text { on January 1, } 2015 \text { due to noncompliance with environmental } \\
\text { limits set down in the integrated permit." (CEZ 2017, p. 113) }\end{array}$ \\
\hline $\begin{array}{l}\text { Voluntary } \\
\text { Compliance }\end{array}$ & $\begin{array}{l}\text { Environmental disclosures related to the voluntary } \\
\text { environmental agreements; standards and certification }\end{array}$ & $\begin{array}{l}\text { "As regards the environment, CEZ Group uses } \\
\text { an environmental management system (EMS) according } \\
\text { to ISO 14001." (CEZ 2017, p. 82) }\end{array}$ \\
\hline
\end{tabular}

Source: Own processing

\section{Content analysis applied to CEZ Group corporate reporting}

CEZ Group is an integrated energy conglomerate having its headquarters in the Czech Republic that holds the majority of company's shares (nearly 70\%). CEZ Group operates in a number of Central and South-eastern European countries ${ }^{3}$ and Turkey. Its main activities consist mainly of electricity distribution, generation, trading and sales (CEZ 2017, p. 2). The managing entity of the Group is the Czech company ČEZ, a. s. that is also the largest company of the Group. CEZ Group is among top 10 largest energy utilities in Europe in terms of installed capacity and number of employees. Table 4. provides basic information about CEZ Group and data related to its operation in its country of domicile.

As a company operating in the energy sector, CEZ Group's operations are associated with negative externalities. It is assumed that the company discloses its CSR practices and policies in publicly available reports to legitimate its operations towards the public. Implementation of whatever means to promote 'social and environmental behaviour' and/or reduction of its environmental footprint represents a cost for the company (e.g. campaigns, donorship, social events, benefits, support of environmental protection, investment in $R \& D$, security measurements etc.). Such costs are to be reflected in the company financial report. Financial reports are audited and therefore it is supposed that the company reports reflect the real state of play of company's efforts towards socially responsible company.

\footnotetext{
${ }^{3}$ Czech Republic, Germany, Poland, Slovakia, Romania, Turkey and countries with limited presence as Ireland,
} Netherlands, Serbia, or Ukraine. 
Table 4: CEZ Group's Profile

\begin{tabular}{lll}
\hline & CEZ Group & Czech Republic \\
\hline Headquarters & Prague, Czech Republic & \\
Ownership & State/privately-owned & \\
State shares (\%) & 69.87 & \\
Countries active & 12 & \\
Number of Customers (mio) & 7.3 & 3.5 \\
Employees & 26,895 & 21,398 \\
Installed Capacity (MW) & 15,620 & 13,351 \\
Net Electricity Generation (TWh) & 54.7 & $\mathrm{n} / \mathrm{a}$ \\
Revenues (bln $€$ ) & 6.5 & 3.0 \\
\hline
\end{tabular}

Source: Own processing (Source: CEZ 2015, 2016, 2017).

Despite the fact that CEZ Group emphasises its responsible behaviour towards its employees, society and the environment, it does not provide actual stand-alone CSR report. The latest CSR report was published in 2014 and the data contained in this report is mainly related to years 2012/2013. Up-todate data of company's CSR practices is incorporated in its annual report (see CEZ 2017). The content analysis conducted in this paper is applied to CEZ Annual Report 2016 within which the Group communicates its CSR practices and policies.

All the disclosed information related to the energy and environment was assigned to aforementioned disclosure categories according to its content and type. The total amount of references coded was 170. It corresponds to the $4.42 \%$ of whole textual part of the report. Examples of disclosures coded are provided in Tables 1., 2. and 3. (see Chapter 3).

The predominant type of disclosures (84\%) was narrative type not providing any quantitative explanations, neither comparisons nor their combinations (see Table 5.). From these results, we can conclude that CEZ Group does not provide detailed information on its policies and company disclose about its policies in general terms.

Table 5: Type of Disclosures (in \% of Total Environmental and Energy Disclosures)

Source: Own processing

\begin{tabular}{lr}
\hline Narrative & 84.08 \\
Narrative-Comparative & 0.00 \\
Quantitative & 13.93 \\
Quantitative-Comparative & 1.49 \\
\hline
\end{tabular}

The content analysis revealed that environmental protection related disclosures significantly prevail over those related to main energy issues (see Fig. 1.). The most frequently disclosed information was related to the nuclear safety that accounts for more than one fifth of all disclosures $(21.89 \%)$. It is also evident that CEZ Group puts considerable emphasis on biodiversity protection and preservation that is the second most striking category in the results of content analysis. Energy sustainability, as a mean of transition towards low-carbon economy, represents a large part in overall environmental disclosures and is the crucial category in energy related disclosures. CEZ group, as one of the major European energy player and significant contributor to environmental pollution, notably discloses information related to air pollution. The direction of company's environmental disclosures reflects its environmental burden that is mainly given by the use of fossil fuels that predominates the production of CEZ Group. 
Figure 1: Results of Content Analysis Applied to CEZ Group

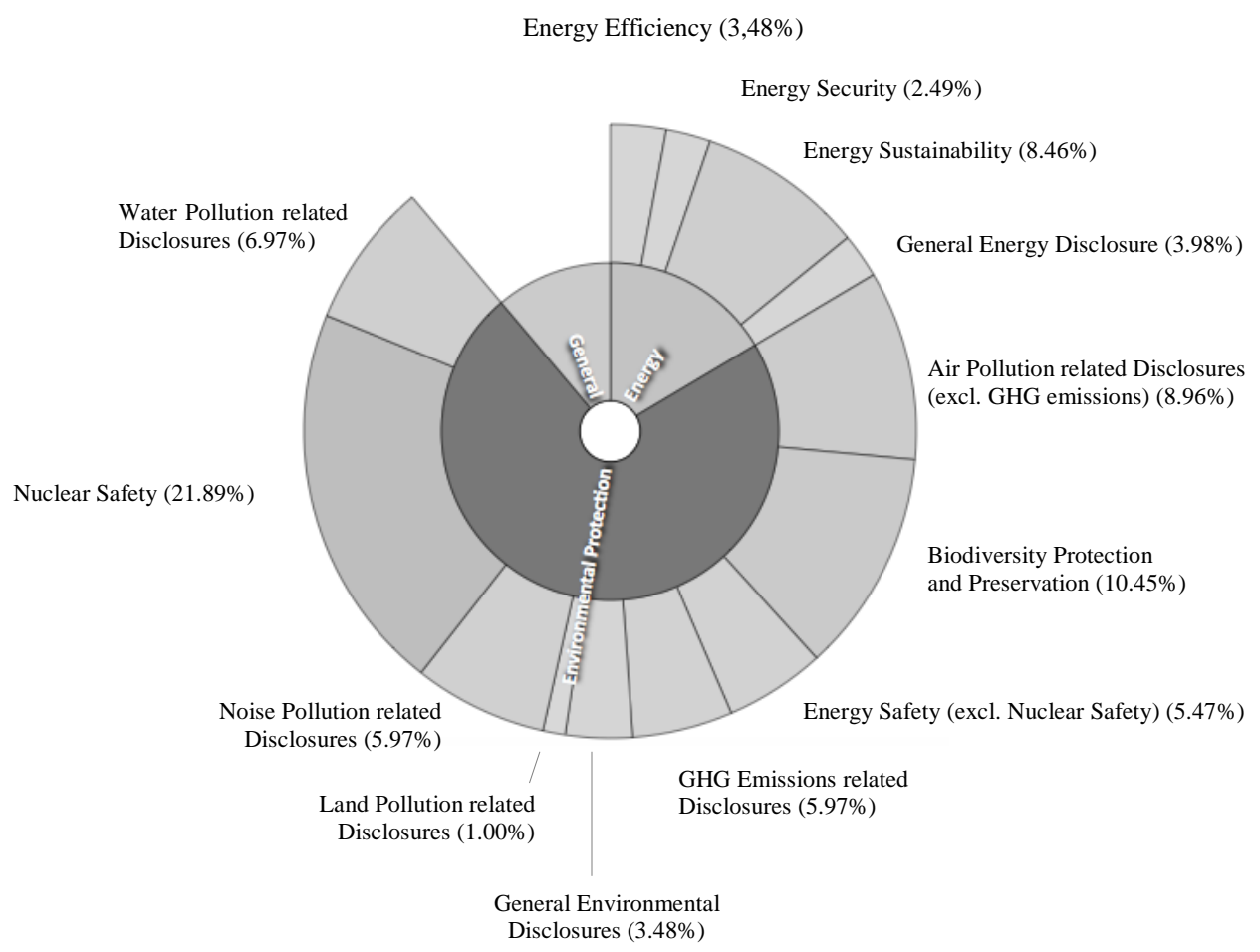

Source: Own processing

CEZ Group also discloses cases of energy and environmental (non-)compliance in its annual report (12.44\% of total coded environmental disclosures). The prevailing cases were related to cases of environmental compliance (see Table 6.). This corresponds the prevalence of environmental protection disclosures communicated by the Group.

Table 6: Cases of Energy and Environmental (Non-)Compliance (in \% of Total Cases)

\begin{tabular}{lr}
\hline Energy Compliance & 16.00 \\
Energy Non-Compliance & 0.00 \\
Voluntary Energy Compliance & 4.00 \\
Environmental Compliance & 60.00 \\
Environmental Non-Compliance & 4.00 \\
Voluntary Environmental Compliance & 16.00 \\
\hline
\end{tabular}

Source: Own processing

\section{Conclusion}

This paper presented the technique of content analysis applied to environmental research according to the unique coding scheme and classification rules developed by authors of this paper. The objective of this paper was to give to the reader an overview of the major methodological problems raised by the use of this technique, and an example of what kind of outcomes can be obtained from content analysis.

The content analysis conducted in this paper was applied to CEZ Group's annual report that is actually the only company report containing company's CSR practices. This was the first necessary step to launch the intended extensive study of social and environmental disclosing in corporate reporting of the tenth largest energy utilities in the EU according to their energy production (in TWh). The processing of content analysis helped to clarify disputable and ambiguous issues and led to the 
improvement of the classification and coding scheme. This study also served to check whether all areas of research and important issues are covered. Content analysis of CEZ Group's annual report does not indicate any specific area or issue that would not be covered in the classification schemes and actual classification and coding schemes seem to be well defined.

When study of corporate reporting of aforementioned tenth largest EU energy utilities is made, intercompany comparisons of each category can be carried out. The outcomes of this extensive study would allow making conclusions about CSR reporting practices of companies across the EU in the context of different energy and environmental policy and orientation of companies' country of domicile. Currently, only inter-category comparison could be presented. Anyway, the temporary results may illustrate how the inter-company comparison can look and what outcomes can be obtained while using content analysis.

This paper also discussed the frequently mentioned issue of subjectivity in the content analysis research. The subjectivity of results of content analysis will be reduced in a further research by comparison of coding sets created by two coders while using the Cohen's kappa test as abovestated.

\section{Acknowledgement}

This paper was supported by Ambassade de France en République Tchèque and Laboratoire d'Économie d'Orléans, UMR 7322 CNRS and Université d'Orléans.

\section{References}

[1] ABBOTT, W. F. and R. J. MONSEN, 1979. On the Measurement of Corporate Social Responsibility: Self-Reported Disclosures as a Method of Measuring Corporate Social Involvement. Academy of Management Journal, vol. 22, issue 3, pp. 501-515.

[2] BEATTIE, V. and S. J. THOMSON, 2007. Lifting the lid on the use of content analysis to investigate intellectual capital disclosures. Accounting Forum, vol. 31, issue 2, pp. 129-163.

[3] BECK, A. C. et al., 2010. Content analysis in environmental reporting research: Enrichment and rehearsal of the method in a British-German context. The British Accounting Review, vol. 42, issue 3, pp. 207-222.

[4] BERELSON, 1952. Content analysis in communication research. Glencoe, III., Free Press.

[5] BRAVO, R., et al. 2012. Corporate Social Responsibility as a Vehicle to Reveal the Corporate Identity: A Study Focused on the Websites of Spanish Financial Entities. Journal of Business Ethics, vol. 107, issue 2, pp. 129-146.

[6] BUHR, N. and M. FREEDMAN, 2001. Culture, institutional factors and differences in environmental disclosure between Canada and the United States. Critical Perspectives on Accounting, vol. 12, pp. 293-322.

[7] CEZ, 2015. CEZ Group Corporate Social Responsibility Report 2012/2013 [online]. [2017-0904]. Available from: from: https://www.cez.cz/edee/content/micrositesutf/odpovednost2013/downloads/CSRR_en.p df.

[8] CEZ, 2016. CEZ Group: The Leader in Power Markets of Central and Southeastern Europe [online].

from: https://www.cez.cz/edee/content/file/investors/investment-stories/equityinvestors_may2016.pdf. 
[9] CEZ, 2017. CEZ Group annual report 2016 [online]. [2017-09-04]. Available from: https://www.cez.cz/edee/content/file/investori/vz-2016/vz-2016-en.pdf.

[10] COHEN, J., 1960. A Coefficient of Agreement for Nominal Scale. Educational and Psychological Measurement, vol. 10, issue 1, pp. 37-46.

[11] CUGANESAN, S. et al., 2010. Examining CSR disclosure strategies within the Australian food and beverage industry. Accounting forum, vol. 34, issue 3-4, pp. 169-183.

[12] FREEMAN, R. E. and D. L. REED, 1983. Stockholders and Stakeholders: A New Perspective on Corporate Governance. California Management Review (pre-1986), vol. 25, issue 3, pp. 88106.

[13] FRIEDMAN, M, 1962. Capitalism and Freedom. University of Chicago Press.

[14] GRAY, R., et al., 1995a. Constructing a research database of social and environmental reporting by UK companies. Accounting, Auditing and Accountability Journal, vol. 8, issue 2, pp. 78-101.

[15] GRAY, R., et al., 1995b. Corporate social and environmental reporting: A review of the literature and a longitudinal study of UK disclosure. Accounting, Auditing \& Accountability Journal, vol. 8, issue 2, pp. 47-77.

[16] GRI, 2016. Consolidated set of GRI Sustainability Reporting Standards 2016 [online]. [201709-04]. Available from: https://www.globalreporting.org/standards/gri-standards-downloadcenter/\#user-details.

[17] GUTHRIE, J. and I. ABEYSEKERA, 2006. Content analysis of social, environmental reporting: what is new? Journal of Human Resource Costing \& Accounting, vol. 10, issue 2, pp. 114-126.

[18] HOOKS, J. and C. J. VAN STADEN, 2011. Evaluating environmental disclosures: The relationship between quality and extent measures. The British Accounting Review, vol. 43, issue 3, pp. 200-213.

[19] HRASKY, S. 2012. Visual disclosure strategies adopted by more and less sustainability-driven companies. Accounting Forum, vol. 36, issue 3, pp. 154-165.

[20] JOHNSON, G. et al., 2008. Exploring corporate strategy, $8^{\text {th }}$ ed. London: Pearson Education Limited.

[21] KRIPPENDORFF, K. 1980. Content Analysis: An Introduction to Its Methodology. London: Sage.

[22] KRIPPENDORFF, K. 2004. Content Analysis: An Introduction to Its Methodology, 2nd ed. London: Sage Publications.

[23] MILNE, J. and R. W. ADLER, 1998. Exploring the reliability of social and environmental disclosures content analysis. Accounting, Auditing and Accountability Journal, vol. 12, issue 2, pp. 237-256.

[24] MITCHELL, R. K., et al., 1997. Toward a Theory of Stakeholder Identification and Salience: Defining the Principle of Who and What Really Counts. Academy of Management Review, vol. 2, issue 4, pp. 853-88.

[25] NEUENDORF, K. A., 2017. The Content Analysis Guidebook, 2nd ed. Cleveland State University, USA: Sage

[26] O'DONOVAN, G., 2000. Legitimacy theory as an explanation for corporate environmental disclosures. Victoria University E-prints Repository [online]. [2017-09-04]. Available from: http://vuir.vu.edu.au/15372/1/O\%27Donovan_2000compressed.pdf. 
[27] O'DONOVAN, G., 2002. Environmental disclosures in the annual report. Accounting, Auditing \& Accountability Journal, vol. 15, issue 3, pp. 344-371.

[28] PARKER, L, 2005. Social and environmental accountability research: a view from the commentary box. Accounting, Auditing \& Accountability Journal, vol. 18, issue 6, pp. 842860 .

[29] PESCI, C. and E. COSTA, 2014. Content Analysis of Social and Environmental Reports of Italian Cooperative Banks: Methodological Issues. Social and Environmental Accountability Journal, vol. 34, issue 3, pp. 157-171.

[30] ROBERTS, C. B., 1991. Environmental Disclosures: A Note on Reporting Practices in Mainland Europe. Accounting, Auditing \& Accountability Journal, vol. 4, issue 3, pp. 62-71.

[31] SAPKAUSKIENE, A. and S. LEITONIENE, 2014. Corporate social responsibility research methods analysis. European Scientific Journal, special edition, vol. 1, pp. 237-244.

[32] SCOTT, W. A., 1955. Reliability of content analysis: The case of nominal scale coding. Public Opinion Quarterly, vol. 19, pp. 321-325.

[33] SUCHMAN, M., 1995. Managing Legitimacy: Strategic and Institutional Approaches. Academy of Management Review, vol. 20, issue 3, pp. 571-610.

[34] SWEENEY, L. and J. COUGHLAN, 2011. Do different industries report Corporate Social Responsibility differently? An investigation though the lens of stakeholder theory. Journal of Marketing Communications, vol. 14, issue 2, pp. 113-124.

[35] TILLING, M. V., 2004. Refinements to Legitimacy Theory in Social and Environmental Accounting. Commerce Research Paper Series, vol. 4, issue 7.

[36] UNERMAN, J. 1999. Methodological issues: Reflection on quantification in corporate social reporting content analysis. Accounting, Auditing \& Accountability Journal, vol. 13, issue 5, pp. 667-680.

[37] VAN STADEN, J. C. and J. HOOKS, 2007. A comprehensive comparison of corporate environmental reporting and responsiveness. The British Accounting Review, vol. 39, issue 3, pp. 197-210.

[38] WOOD, D. J., 1991. Corporate Social Performance Revisited. The Academy of Management Review, vol. 16, issue 4, pp. 691-718.

[39] ZÉGHAL, D. and S. A. AHMED, 2002. Comparison of Social Responsibility Information Disclosure Media Used by Canadian Firms. Accounting, Auditing \& Accountability Journal, vol. 3 , issue 1 , pp. 38-53. 